\title{
Community development workers as agents of change and conduit of authentic public participation: The case of Mpumalanga Province in South Africa
}

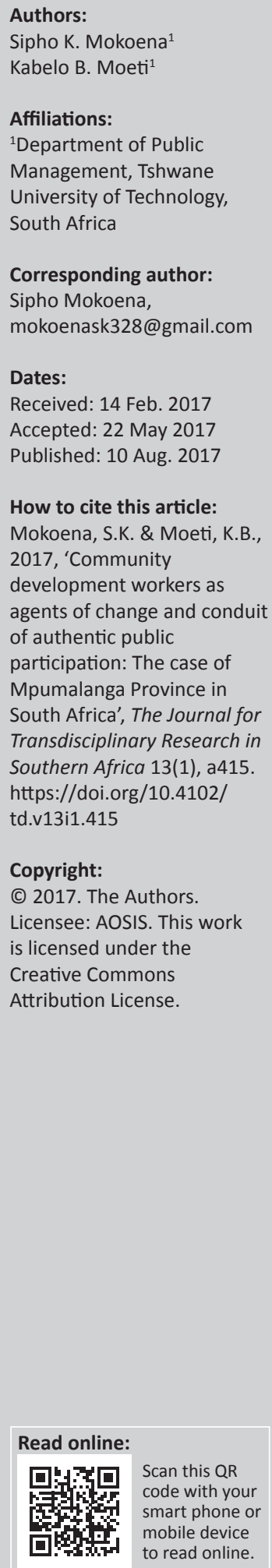

\begin{abstract}
This article explores the role of community development workers (CDWs) in the Mpumalanga Province of South Africa. The CDWs are by law expected to regularly communicate, inter alia, government initiatives in a way which is easily accessible to community members. Literature shows that the CDWs forward concerns and issues on the service provided by national and provincial government in general, and local government to be specific. This article acknowledges that CDWs share the working space with Ward Committees who have a direct say in the planning, decision-making and project implementation that have impact on their respective wards. The question that this article attempts to answer is whether the establishment of CDWs in the country has achieved the desired result to the extent that it can be recommended for permanent incorporation in the local municipality structures. The research design used in this article was a qualitative method. Data were collected through extensive review of public documents, accredited journal articles, observations and interviews. The results showed that the CDWs coordinate teams of volunteers in community projects, coordinate teams employed on public works programmes, help communities develop and submit proposals for inclusion in integrated development plans to municipalities, and other spheres of government or donors. Furthermore, the roles and functions of both CDWs and Ward Committees do overlap. It is very difficult for the local communities to differentiate between these two structures.
\end{abstract}

\section{Introduction}

In 2003, the South African government introduced the community development workers (CDWs) system administered at the provincial sphere, but operating in municipalities according to the geographic demarcation of their wards. CDWs are appointed public servants governed by the Public Service Act 1994 (Act 103 of 1994) (Ministry for Public Service and Administration 2007). According to the former Minister of Public Service and Administration, Minister Fraser-Moleketi (2007), CDWs are a fundamental building block of the public service registering an important step forward in South Africa's developmental agenda. Thus, this article argues that CDWs are formed to bridge the gap between government and citizens in great need of services provided by it. It is a complementary structure to existing structures in municipalities with different, and to a certain extent, some overlapping, responsibilities to other structures such as Ward Committees and Ward Councillors. These structural arrangements were formed to promote public participation and democracy to people where they live. The research problem that this article attempts to address is as follows: with the recent community protests experienced in Mpumalanga Province, CDWs may be able to play a role in identifying causal factors of the protests while enhancing citizen participation (however, acknowledging the existence of other important stakeholders such as Ward Committees, Ward Councillors, non-governmental organisations [NGOs] and business community, just to mention a few). The article initiates discussion by presenting the geographical location of Mpumalanga Province; thereafter follows a discussion on the theoretical foundation of the roles and responsibilities of CDWs. Secondly, the research methodology used in this article is explained briefly. Thirdly, an analysis and interpretation of the empirical findings are presented. Finally, the article provides concluding remarks.

\section{Location of Mpumalanga Province}

The province of Mpumalanga is one of the nine post-1994 provinces in the Republic of South Africa. Mpumalanga Province is a culmination of mainly the former KwaNdebele, KaNgwane, parts of the former Lebowa and Gazankulu homelands in the Bushbuckridge Local Municipality areas (Municipal Demarcation Act 1998 [Act 27 of 1998]). In terms of the above-mentioned Act, 
Mpumalanga Province (see Annexure 1) is divided into three distinct districts, namely Nkangala, Gert Sibande and Ehlanzeni.

\section{Nkangala District}

Nkangala District in Mpumalanga Province comprises mainly the former homeland KwaNdebele, former Witbank now known as Emalahleni, some north-eastern parts formerly attached to the province today known as Gauteng, Middelburg and the respective surrounding farmlands areas.

\section{Gert Sibande District}

Gert Sibande is in Mpumalanga Province comprising areas previously under the northern-eastern KwaZulu-Natal homeland, the main power or energy supply industry areas of the pre-1994 Eastern Transvaal Province and their adjacent enormous streaks of farmlands.

\section{Ehlanzeni District}

The Ehlanzeni District of Mpumalanga Province comprises, among others, mainly former KaNgwane homeland areas, also former Lebowa and Gazankulu homelands. Ehlanzeni is the biggest district in terms of population in the province, but it is constituted by only 5 of the 18 municipalities in the province, namely Nkomazi, Umjindi, Thaba Chweu, Bushbuckridge and Mbombela, the capital city of the province (Municipal Demarcation Act 1998 [Act 27 of 1998]).

The local municipalities where the study forms its base comes from the above-mentioned districts with each district represented by one local municipality, namely Emalahleni (Nkangala District), Msukaligwa (Gert Sibande District) and Thaba Chweu (Ehlanzeni District) (Van Rooyen and Mokoena 2013). The current population is estimated to be approximately 4600000 in 1165000 households (Republic of South Africa 2011).

\section{Theoretical framework of community development worker programme}

CDWs can be defined as participatory change agents who work in the communities where they live, and to whom they answer for their activities. CDWs are expected to help community members to understand how they can participate in the plans for development in their communities. They are expected to facilitate community participation in policymaking and implementation, and in service delivery (Ministry for Public Service and Administration 2007). As mentioned above, Community Development Workers Programme (CDWP) was introduced in 2003 as a national mandate to fast-track service delivery and development in various local municipalities. CDWP was registered as an alternative to a conventional policy model to service delivery backlogs (Tshishonga and Mafema 2010: 562). The researchers argue that the CDWP is a South African government democratic approach to social welfare. The White Paper on Social Welfare 2007 summarises this approach as follows:

The goal of developmental social welfare is a humane, peaceful, just and caring society which will uphold welfare rights, facilitate the meeting of basic human needs, release people's creative energies, help them archive their aspirations, build human capacity and self-reliance, and empower them to participate fully in all spheres of social, economic and political life. In this connection, it is vivid that this particular programme was established to enhance the public participation in order for people to identify with the government programmes in their different communities. South Africans will be afforded the opportunity to play an active role in promoting their own well-being and in contribution to the growth and development of our nation. The challenge facing the welfare system is to devise appropriate and integrated strategies to address the alienation and the economic and social marginalization of vast sector of the population who are living in poverty, are vulnerable, and have special needs. An inter-sectoral response is needed within government and between government and civil society to adequately address welfare needs. (Republic of South Africa 2007)

In the 2003 State of the Nation Address, the former president, Thabo Mbeki, presented the rationale for the CDWP stating that government will create a public service echelon of multiskilled CDWs who will maintain direct contact with people where these masses live. The aim is to ensure that government goes to the people so that it sharply improves the quality of the outcomes of public expenditure intended to raise the standards of living of the people.

The above paragraph serves to illustrate the significance of structures like CDWs in this case, to be multi-skilled because they work in direct contact with communities to ensure that citizens have access to quality services. CDWs are expected to be knowledgeable about services provided by various departments in all the spheres of government. It is essential that all spheres of government cooperate to give citizens a complete package of services that will improve their conditions. The Ministry for Public Service and Administration (2007:8) further states that well-trained CDWs will help enrich the quality of government services for communities by identifying new programmes and creating linkages and coordination with other community stakeholders. For example, CDWs will help people access information and services to set up communitybased projects such as small business development projects. The CDWP is based on the following objectives as identified by the Ministry for Public Service and Administration (2007:9):

- to deepen democracy

- to contribute to citizen education

- to ensure integration and coordinated function of government at all spheres and between departments

- to raise skills levels within local government

- to improve the dissemination of information to all sectors of society.

The idea is to facilitate developmental projects easier while at the very same time, the local people are being skilled on any project that may be running at the time in their locality. In this regard, Ham, Chirwa and Theron (2013:179) argue that 
people-centred approaches in community forestry are based on three very important principles, namely (1) the active and authentic participation of community stakeholders in projects, (2) the use, and acknowledgement, of the importance of indigenous knowledge system (IKS) and (3) the use of policies that support participation and collaborative management of resources. They argue further that the CDWP emphasises the importance of a holistic approach, of codeveloping a customised local context, the relevant solutions to problems through two-way information flow, which refers to a mutually beneficial social learning process, of partnership planning between the change agent and the local community, and of the acknowledgement of IKS. Taken in the light of the above contribution of Ham, Chirwa and Teron, it can be concluded that CDWs are expected to work essentially as change agents.

\section{Roles and functions of community development workers}

The Ministry for Public Service and Administration (2007) describes the roles of CDWs as follows:

- to assist in the smooth delivery of services by identifying and removing obstacles

- to strengthen the social contract between government and communities

- to link communities with government services

- to pass on communities' concerns and problems to government structures

- to support and nurture the increased exchange of information

- to improve government-community networks.

The above serve to emphasise the significance of government working together with local communities. An observation can be made, based on media reports, that communities are mostly feeling that government is not communicating enough, and as such they are left behind on matters affecting them directly. In essence, CDWs are formed to bridge the gap between government and citizens in great need of services provided by it. It is a complementary structure to existing structures in municipalities.

\section{Advantages of community development workers}

The former President Mbeki on 14 March during the CDWs Indaba (Summit) in Tshishonga and Mafema (2010:574) argued that CDWP had brought in a new category of professionalism in the local government sphere and would assist and fast-track service delivery. It had a structural resource budgeted for its effective and efficient operations. The CDWP was formed on the basis of the following strategic objectives and advantages:

- to assist in the removal of development and service delivery bottlenecks

- to link communities with government services and relay community concerns and problems to government
- to support, nurture and advocate for an organised voice for the poor

- to improve government community networks (The Presidency 14 March 2008 'SA: Mbeki: Community Development Workers Indaba (Summit)' in Tshishonga \& Mafema 2010:574).

The above advantages have been summarised by the Forum for Australian Services for Survivors of Torture and Trauma (FASSTT) in Tshishonga and Mafema (2010:575) as a process which contributes to the strength of a community by increasing its social capital, developing self-reliance through encouraging cohesive relationships and external partnerships, enhancing and harnessing community skills and resources, and promoting participation in decision-making leadership to ensure community ownership.

\section{Disadvantages of community development workers}

According to Tshishonga and Mafema (2010:575) the disadvantages of CDWs during the stage of its formation are as follows:

- The CDWP is a cumbersome programme: it is based in the Department of Cooperative Governance and Traditional Affairs (COGTA), but is overseen by the whole municipalities as the locus of their day-to-day activities. Therefore, the CDWP was conceived without a policy direction.

- Communities did not trust the programme because of new suspicion that the CDWs spy for the government, a legacy of the previous oppressive government. The South African culture is built on suspicion of top-down and state-led community development programmes as they were used during the apartheid to control people.

- The role and responsibility of theCDWs are misunderstood by both local government and communities, and it often causes conflict and tension (Gray \& Mubangizini 2010; Tshishonga \& Mafema 2010).

- The issue of programme accountability was an added challenge as councillors had an expectation that CDWs were to report directly as councillors had an expectation that CDWs were to report directly to them, thus there was confusion as to who was in charge of them. This resulted in fragmented and uncooperative relationships and networks between ward councillors and CDWs (Gray \& Mubangizini 2010; Tshishonga \& Mafema 2010).

- The local government officials and Councillors felt threatened by CDWs' position and direct line communication to the COGTA. CDWs were thus treated with suspicion in case they assumed the government and councillor's roles.

- The suspicions and infighting with political stalwarts of the communities placed CDWs in a precarious position where they felt exacerbated by the lack of a formal introduction of the programme, particularly to the relevant stakeholders such as government departments, the private sector and communities as targeted recipients of their services. 
The above disadvantages present the fallacy and misconception by both local government officials and councillors about CDWs at its inception. However, its main aim as discussed by Van Rooyen (2007) in Tshishonga and Mafema (2010:577) that CDWs are an effective way of removing development deadlock caused by bureaucratic and top-down development practices as well as strengthening the democratic social responsibility by giving voice to the poor and improving the relationship between a municipality and communities to build a responsible and accountable government. Figure 1 presents the roles and responsibilities of councillors, Ward Committees and CDWs as the roles are supposed to complement each other. The researchers acknowledge that this article focuses primarily on CDWs; however, it was deemed fit to depict some similarities and differences of the three role players because they are all operating in the same space.

Figure 1 serves to clarify the distinct roles and responsibilities of councillors, Ward Committees and CDWs as persons that are expected to be working with citizens on governance issues. In as far as the councillors are concerned, for example, it should be noted that councillors are politically elected representatives who live in and service the ward. Furthermore, councillors are required to manage queries and complaints, resolve disputes and refer unresolved disputes to the municipality and work with Ward Committees to draw up an annual plan of activities. Regarding Ward Committees, for example, they are structures elected from the communities in a ward general meeting to represent sectoral interest. A Ward Committee is formed by 10 members and is chaired by the Ward Councillor. And it is supposed to be apolitical and should be involved in matters such as the Integrated Development Plan (IDP) process, municipal performance management, the annual budget, council projects and other key activities. Moreover, it can support the councillor in dispute resolution and can identify and initiate projects to improve the lives of people in the ward. CDWs are appointed as public servants governed by the Public Service Act 1994 (Act 103 of 1994) and are expected, for example, to regularly communicate government and other information to communities in an accessible way, pass concerns and issues on the service delivery, inform communities about problems in the delivery of basic services and help implement projects. It can be argued that all the above roles and responsibilities of three actors serves to enhance the involvement and participation of citizens in the governance of municipalities. However, it should be noted that, for example, roles such as managing complaints (by the councillor), identification of projects to improve the lives

\begin{tabular}{|c|c|c|}
\hline Councillors & Ward Committees & Community Development Workers (CDWs) \\
\hline $\begin{array}{l}\text { Politically elected representatives who live in and } \\
\text { service the ward. } \\
\text { The Ward Councillor: } \\
\text { - Chairs the ward committee. } \\
\text { - Convenes the constituency meeting to elect Ward } \\
\text { Committee members. } \\
\text { - Calls committee meetings. } \\
\text { - Ensures a schedule of meetings is prepared, } \\
\text { including Ward Committees and constituency } \\
\text { meetings. } \\
\text { - Works with the Ward Committee to draw up an } \\
\text { annual plan of activities. } \\
\text { - Handles queries and complaints. } \\
\text { - Resolves disputes and refers unresolved disputes } \\
\text { to the municipality } \\
\text { - Should be fully involved in all community activities. } \\
\text { The proportional representative councillor: } \\
\text { - Should attend Ward Committee meetings, } \\
\text { constituency meeting and special meetings. } \\
\text { - Can assist with resolving disputes and making } \\
\text { referrals. } \\
\text { the Ward Councillor. }\end{array}$ & $\begin{array}{l}\text { Up to } 10 \text { community or sectoral representatives } \\
\text { elected at a ward general meeting to represent } \\
\text { sectoral interest. The committee is the centre of } \\
\text { local government. } \\
\text { A Ward Committee: } \\
\text { - Takes issues of local concern to the councillor, } \\
\text { who in turn takes these to council. } \\
\text { - Has a direct say in the planning, decision-making } \\
\text { and project implementation that have an impact } \\
\text { on their ward. } \\
\text { - Increases the participation of local residents in } \\
\text { municipal decision-making. } \\
\text { - Is not politically aligned. } \\
\text { - Should be involved in matters such as the } \\
\text { integrated development planning process, } \\
\text { municipal performance management, the annual } \\
\text { budget, council projects and other key activities. } \\
\text { - Can identify and initiate projects to improve the } \\
\text { lives of people in the ward. } \\
\text { - Can support the councillor in dispute resolution. } \\
\text { - Can monitor the performance of the } \\
\text { municipality and take issues of concern to the } \\
\text { local ward. } \\
\text { - Can help with community awareness campaigns } \\
\text { on issues such as waste, water and sewage, } \\
\text { payment of fees and charges. } \\
\text { - Forward names of prospective CDW candidates } \\
\text { from their respective wards for learnership. }\end{array}$ & $\begin{array}{l}\text { The CDW is expected to: } \\
\text { - Regularly communicate government and other } \\
\text { information to communities in an accessible way. } \\
\text { - Pass concerns and issues on to the service } \\
\text { providers. } \\
\text { - Coordinate teams of volunteers in community } \\
\text { projects, coordinate teams employed on public } \\
\text { works programmes, help communities develop } \\
\text { and submit proposals for inclusion in intergraded } \\
\text { development plans to municipalities, other } \\
\text { spheres of government or donors. } \\
\text { - Coordinate inter-departmental programmes and } \\
\text { encourage integration. } \\
\text { - Maintain communication with Community Based } \\
\text { Organisations and workers. } \\
\text { - Promote the principles of Batho Pele and } \\
\text { community participation. } \\
\text { - Inform communities about problems in the } \\
\text { delivery of basic services. } \\
\text { - Help implement projects. } \\
\text { - Liaise with and advocate on behalf of } \\
\text { communities with parastatals, NGOs and private } \\
\text { donors. } \\
\text { - Monitor, evaluate and report on the impact of } \\
\text { - Hevelopmental projects. } \\
\text { TB, HIV and AIDS) and intensify education and } \\
\text { of a better life for all. } \\
\text { other health matters. } \\
\text { - } \text { servant. }\end{array}$ \\
\hline
\end{tabular}

Source: Adapted from a handbook for CDWs, 2005:23.

FIGURE 1: Roles and responsibilities of Ward Councillors, Ward Committees and community development workers. 
of people in the ward (by Ward Committees) and communicate problems in the delivery of basic services to communities have a potential of power struggle and conflict over who has authority over the ward. These roles, for example, seem to have some overlapping responsibilities. However, both Ward Committees and CDWs were formed to bring and enforce democracy to people where they live (Republic of South Africa 2005).

\section{Research methodology}

The qualitative research methodology was utilised in this study in order to be in a position to evaluate the impact by CDWs in relation to citizen participation on governance issues regarding services delivery. Qualitative research was deemed suitable for gaining a rich understanding of CDWs' roles in enhancing citizen participation towards municipal service delivery and finding out the representatives of the local communities' views on the above-mentioned structures' roles and their performance in municipal service provision, in the research areas. In attempting to study the above-noted dynamics, a case study of three local municipalities in the province was identified, namely Thaba Chweu (Ehlanzeni Region), Msukaligwa (Gert Sibande Region) and Emalahleni (Nkangala Region). The researchers used the qualitative research approach as it offers greater depth of understanding. As such, the qualitative method usefully allowed the researchers to explore and highlight the challenges confronting CDWs towards enhancing citizen participation.

The research utilised multiple data collection strategies to collect the necessary data. This includes the literature review, observations, analysis of statistics already produced by others, official publications and correspondence discussion documents, official papers presented at workshops and conferences, speeches and debates, newsletters and pamphlets, newspaper surveys, theses and dissertations as well as material from the Internet. Primary data were collected through semi-structured interviews. The sample of the study comprised a total of 65 participants consisting of 9 Ward Councillors, 31 Ward Committee members and 25 CDWs from all the three local municipalities. The sample breakdown from the three municipalities is as follows:

- Thaba Chweu Local Municipality - 3 Ward Councillors (sample) from the 14 wards (population) as per the municipality's demarcation, 10 Ward Committee members (sample) (5 wards represented by 2 members) from 140 members (population) and 8 CDWs (sample) from 14 wards (population).

- Msukaligwa Local Municipality - 3 Ward Councillors (sample) from the 16 wards (population) as per the municipality's demarcation, 10 Ward Committee members (sample) (5 wards represented by 2 members) from 160 members (population) and 8 CDWs (sample) from 16 wards (population).

- Emalahleni Local Municipality - 3 Ward Councillors (sample) from the 34 wards (population) as per the municipality's demarcation, 11 Ward Committee members (sample) ( 6 wards represented by 2 members, of whom 1 ward member withdrew at the last minute) from 340 members (population) and 9 CDWs (sample) from 34 wards (population).

The sample of the wards was randomly selected with a consideration of a geographical distance from one ward to another. This was done for convenience purposes about the distance that the researchers had to cover within the limited resources and time.

The data collected through semi-structured interviews were analysed by using a thematic content analysis. Braun and Clarke (2006) argue that a thematic analysis is a qualitative analytic method for identifying, analysing and reporting patterns (themes) within data. It minimally organises and describes a data set in (rich) detail. However, frequently it goes further than this, and interprets various aspects of the research topic. Creswell (2003) asserts that an analysis in qualitative research consists of exploring the data, writing down ideas and thinking about the organisation of the data in text segments or themes. Braun and Clarke (2006) further state that a theme captures something important about the data in relation to the research question and represents some level of patterned response or meaning within the data set. The following steps suggested by Leedy and Ormrod (2001) were followed when carrying out the thematic analysis in this study:

- organisation of details about the case

- categorisation of single instance

- identification of patterns

- synthesis and generalisation.

\section{Analysis of results}

The following responses by CDWs have been categorised into six, namely the establishment of Ward Committees, membership and composition, functions, roles and responsibilities, community participation processes; training and capacity building and general. As mentioned above, these classifications were made to provide a systematic flow of the responses and create an order for the analysis and writing of the article. Furthermore, it should be noted that CDWs' roles cannot be looked at in isolation from other stakeholders like Ward Committees' and Ward Councillors' roles.

On the establishment of Ward Committees and CDWs, the respondents (CDWs) were asked if their local municipalities have adopted a policy on how Ward Committees should carry out their roles and functions. All (100\%) respondents indicated that the various municipalities had adopted policies on how Ward Committees and CDWs should carry out their roles and functions. This symbolises the commitment that the various local municipalities have shown on the whole concept of both Ward Committees and CDWs. In addition, the respondents were asked if the respective councils budgeted for the functioning and support of Ward Committees. As many as $70 \%$ of the respondents indicated that there is a budget that has been put aside for community participation, but they were unsure whether it was mainly for the functioning and 
support of Ward Committees and CDWs. Only the remaining $30 \%$ of the CDWs confidently responded that the various councils had actually budgeted for the functioning and support of Ward Committees and CDWs.

Regarding the membership and composition of the Ward Committees, the respondents were asked about the term of office that the various local municipalities set for Ward Committees. All (100\%) respondents indicated that the term of office that their various local municipalities had set for Ward Committees was five years. This is in line with the current council's term of office. A follow-up question to respondents was in relation to whether, in their view, Ward Committees generally were representative of race and gender. It was very interesting to observe that all (100\%) respondents indicated that race and gender were not issues for them, because of the fact that the current wards spread across the former White, mixed race, Indian and African townships or residential areas. Instead, they were more interested in ensuring service delivery to the communities. Issues of representativity would appear to be at the core of the Ward Committee's purpose, that is, legislative provisions make it clear that the policy intention was to bring a full spectrum of demographically defined and sectoral groups into the Ward Committee system.

In as far as the function, roles and responsibilities of both CDWs and Ward Committees are concerned, the minority of the respondents (37\%) felt that Ward Committees are accountable, in the sense that they have some form of mechanism to account to the local constituency for their actions and responsibilities. However a significant $63 \%$ did not agree. However, this portion mentioned the general dysfunctionality in the Ward Committees and CDWs as being frequently related to a lack of resources. Furthermore, the $37 \%$ of respondents agreed that Ward Committees do account for their actions to their local constituency through sub-forums of the ward, regular meetings that are open to the public, community report-back meetings. While the $63 \%$ disagreed. In addition, when respondents replied on the question whether the municipalities have delegated any specific powers to CDWs and Ward Committees, the respondents indicated that it does not appear that there is any significant delegation of powers to Ward Committees and CDWs - an option that exists within the legislation. A clear majority $(70 \%)$ of the respondents indicated that no powers were delegated to Ward Committees and only $20 \%$ disagreed with this view, while $10 \%$ were still unsure on this issue. Moreover, on issues of whether the various councils have systems within their respective councils to get reports from these structures, all (100\%) respondents indicated that the Ward Councillors are expected to hold public meetings once a month. It is at these meetings that they are expected to deal with, among other issues, concerns of the local community members, issues of CDWs, etc. It was interesting to find out that these structures do submit reports on meetings held to Office of the Speaker or the Office of the Municipal Manager, which then forms part and parcel of their reports and recommends them for the various municipal councils for adoption.
With regard to community participation processes, the participants were asked how they would define community participation in the context of their local municipalities. Although the respondents came up with different definitions, all their responses included the following: that all stakeholders, including the broader public, should be afforded an opportunity to make inputs into the municipal affairs. As such, examples given to activities that stakeholders do participate in include the IDP review process, IDP representative forum, the budget and the performance management system. In addition, all (100\%) respondents agreed that the CDWs do have an impact in the various councils' decision. However, it was interesting to hear from the respondents when they were asked if there is any link between CDWs and Ward Committees. The respondents indicated clearly that there is confusion to a certain extent on operational grounds because of the overlap in functions while the legislations are there to guide the working relationship between the Ward Committees and CDWs. The largest percentage of respondents (52\%) felt that there was no link, while $27 \%$ perceived a link and $21 \%$ were unsure and stated that both the CDWs and Ward Committees are part of the government structures that serve the local people and have to work together to improve the lives of the poor. It was clear to the researchers that there is still confusion in terms of the roles and functions of both the Ward Committees and CDWs. This sometimes results in conflict. In as far as the challenges facing the implementation of the CDWP and what remedial actions would they recommend. All (100\%) respondents felt that the only challenge facing CDWs was the lack of maximum exposure in fulfilling their roles and responsibilities. Moreover, on the question whether the respective local municipalities are doing enough to promote community participation, $62 \%$ of respondents felt that the local municipalities were doing enough to promote community participation and CDWs as all structures and systems for community participation were properly in place. However, $38 \%$ disagreed completely. The respondents were asked about what can be done to improve overall community participation in your local municipality. Although all the respondents came up with different viewpoints, a clear message from them was that CDWs should be a major supporting engine of all community participation processes in local municipalities. All the respondents felt that the non-partisan nature of both CDWs and Ward Committees is an important ingredient in the enhancement of public participation at local government.

On the training and capacity building, the question was asked on the kinds of training or capacity building CDWs and Ward Committees have received in order to fulfil their intended functions. The largest percentage of respondents (85\%) said that this training had in fact improved Ward Committee performance, whereas $15 \%$ said it had not. Those who said that the training had been effective held the view that it had helped Ward Committee members and Ward Councillors to understand their roles and therefore to become more effective. Generally, those who felt that the training had been ineffective did not explain how and simply indicated that it had not produced the expected results. 
In general, in view that the CDWs are salaried government officials, all respondents felt that the Ward Committees should be remunerated. The obvious reason for remunerating Ward Committee members was that many were drawn from indigent communities and were required to undertake public interest activities, whereas their own livelihoods were not secure. It was, however, mentioned that the only significant form of compensation that had occurred was for the payment of transport costs.

\section{Ethical considerations}

The authors would like to confirm that all ethical considerations were adhered to when writing this article.

\section{Discussion and conclusion}

The researchers observed that the role played by both CDWs and Ward Committees in local municipalities create the platform for public participation process as these structures are links between the public and the local municipalities as this was meant to improve communication channels within local government. Furthermore, both these structures are perceived by the communities as credible and competent structures to present the communities' demands to local municipalities and was proven by the findings of this research. However, the public does not differentiate between the CDWs and Ward Committees. The role played by CDWs has a better part of improving the government communication network in linking the public with government services. The CDWs are by law expected to regularly communicate government and other information to communities in an accessible way, while at the very same time the Ward Committees are by law expected to take issues of local concern to the councillor, who in turn takes these to the council. Furthermore, the CDWs pass concerns and issues on to the service providers, and the Ward Committees have a direct say in the planning decision-making and project implementation that have an impact on their wards. In this connection, it is interesting to observe that the CDWs coordinate teams of volunteers in community projects, coordinate teams employed on public works programmes, help communities develop and submit proposals for inclusion in intergraded development plans to municipalities, other spheres of government or donors, while the Ward Committees increase the participation of local residents in municipal decision-making, just to mention a few legislative roles. In essence, the roles and functions of both CDWs and Ward Committees do overlap and they create conflict among these two structures. It is very difficult for the local communities to differentiate between these two structures. This conclusion is supported by the responses of the community members as presented above.

The article concludes by providing the following recommendations: (1) In order to improve the effectiveness of the Ward Committees and CDWs in municipalities, there is a need to improve cooperation and coordination in the rendering of government services by its institutions, and in this case, the municipalities. The philosophy behind the introduction of the IDP in all municipalities in the country was to improve cooperation and coordination. The constraint with the IDP process is that most municipalities do not have the capacity to facilitate it timeously. In most cases, the IDP is a document for audit purposes but it will not necessarily influence the delivery of services within the municipality. This could be done if the Ward Committees, Councillors and CDWs work together in all initiatives that require their cooperation. (2) The municipalities should continuously provide Ward Committees and CDWs with appropriate capacity-building or training programmes in order for them to function effectively. Ward Committees' training strategies should take cognisance of the unique nature of Ward Committees as fragile voluntary bodies that are still in the process of exploring and building upon this uniquely structured model of participatory democracy. These training programmes should also attempt to accommodate the different academic backgrounds of the Ward Committee members. The local municipalities should also conduct a careful participatory review of Ward Committee experiences and local knowledge bases before planning any further Ward Committee training and capacity-building programmes. Some successful examples of capacity and training approaches emphasise the importance of building on past experiences and gains in capacity. The above approach could also be applied to the CDWs as well, because they are appointed as public officials. This can only be accomplished by working with beneficiaries in an interactive manner and focusing on the key development challenges and issues that are identified by both internal stakeholders, for example CDWs, and external service providers. Building the capacity of Ward Committees and CDWs must go together with deepening the interaction between Ward Committees, councillors, CDWs and the communities, to ensure that it is really the communities that can take advantage of newly empowered Ward Committees and CDWs. (3) The researchers recommend that further studies should be conducted with a view to fusing the two structures into one. This is supported by the fact that certain roles, functions and responsibilities do overlap, for example informing the citizens about projects, just to name one.

\section{Acknowledgements}

The corresponding author would like to acknowledge and thank the Tshwane University of Technology for offering him the opportunity to study his doctoral degree.

\section{Competing interests}

The authors declare that they have no financial or personal relationships which may have inappropriately influenced them in writing this article.

\section{Authors' contributions}

This study was completed by S.K.M for his doctoral degree. S.K.B was responsible for the conceptualisation of the article, 
analysed and interpreted the data. K.B.M. was the supervisor and made conceptual contributions, proofread and supervised the writing of the article.

\section{References}

Braun, V. \& Clarke, V., 2006, 'Using thematic analysis in psychology', Qualitative Research in Psychology 3(2), 77-101.

Creswell, J.W., 2003, Research design: Qualitative, quantitative and mixed methods approaches, 2nd edn., Sage Publication, New Delhi.

Gray, M. \& Mubangizi, B.C., 2010, 'Caught in the vortex: Can local government community development workers succeed in South Africa?', Community Development Journal 45(2), 188-197.

Ham, C., Chirwa, P. \& Theron, F., 2013. The forester as a change agent - from trees between the people to people between the trees, the development change agent: A micro-level approach to development, Van Schaik, Pretoria.

Ministry for Public Service and Administration, 2007, Address by Minister FraserMoleketi on the roles of Community Development Workers, Government Printers, Pretoria.
Leedy, P.D. \& Ormrod, J.E., 2001, Practical research: Planning and design, 7th edn., Prentice-Hall, Upper Saddle River, NJ.

Republic of South Africa, 1994, Public Service Act (Act no. 103 of 1994), Government Printers, Pretoria.

Republic of South Africa, 1998, Municipal Demarcation Act (Act no. 27 of 1998), Government Printers, Pretoria.

Republic of South Africa, 2005, Handbook for community development workers, Government Printers, Pretoria.

Republic of South Africa, 2007, White paper on social welfare, Government Printers, Pretoria.

Republic of South Africa, 2011, Statistics South Africa, Government Printers, Pretoria.

Tshishonga, N. \& Mafema, E.D., 2010, ‘Policy development for service delivery through community development workers Programme in South Africa: Exploring the implications of placing a cart before the horse', Journal of Public Administration 45(4), 561-583.

Van Rooyen, D., 2007, 'Community development workers: Four lessons from international experience of community-based workers', Journal of Social Work 43(3), 209-223.

Van Rooyen, E.J. \& Mokoena, S.K., 2013. 'The role of ward committees towards enhancing public participation: The case of the Mpumalanga Province, South Africa', Journal of Business and Economics 4(8), 761-770. 
ANNEXURE 1: Location of Mpumalanga Province, South Africa.
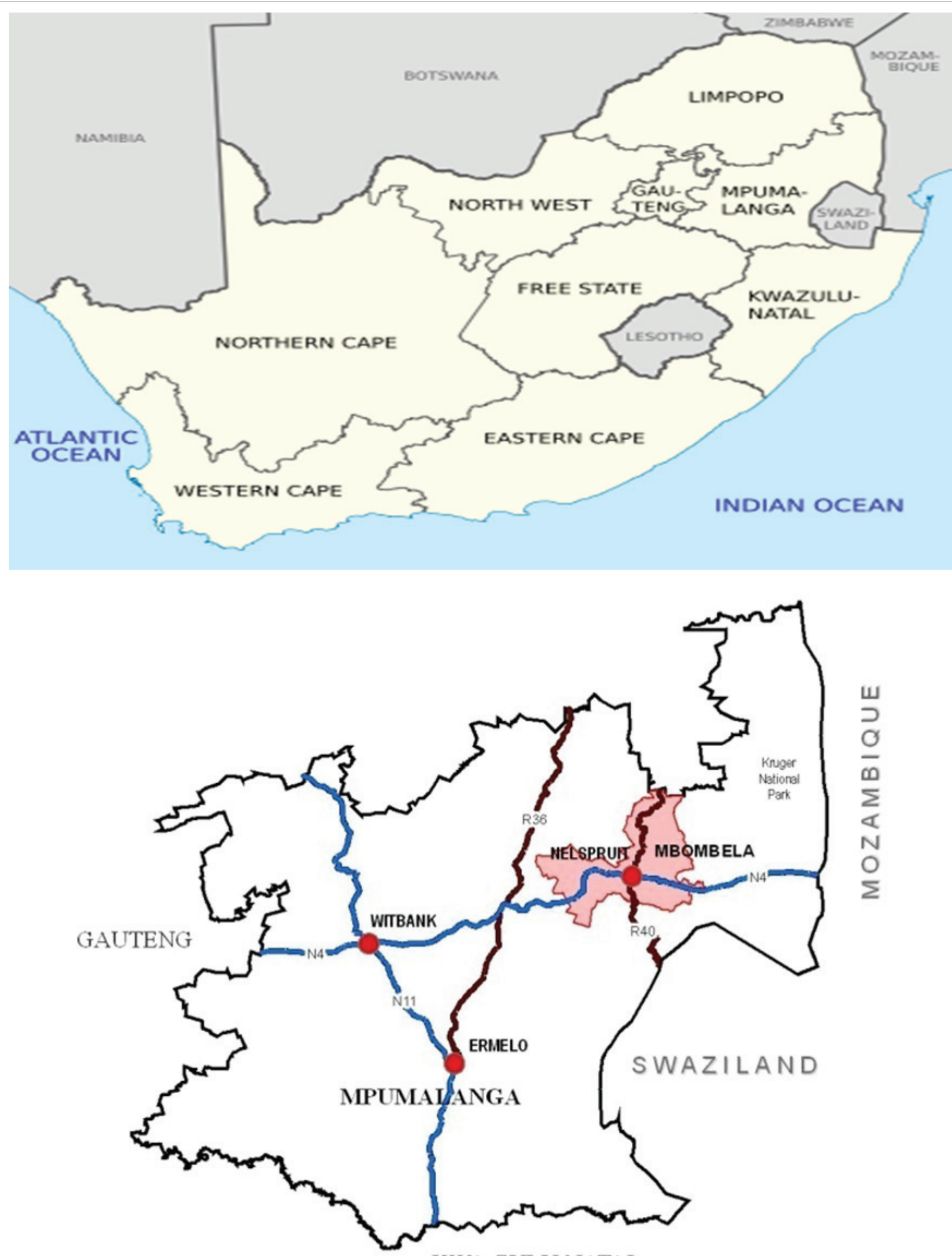

KWA-ZULU NATAL 